EESTI NSV TEADUSTE AKADEEMIA TOIMETISED. XVII KOIDE

KEEMIA * GEOLOOGIA. 1968, Nr. 3

ИЗВЕСТИЯ АКАДЕМИИ НАУК ЭСТОНСКОЙ ССР. ТОМ ХVII

ХИмИЯ * ГЕОЛОГИЯ. 1968, № 3

\author{
E. LIPPMAA, T. PEHK
}

\title{
CARBON-13 CHEMICAL SHIFTS OF SUBSTITUTED NORMAL ALKANES
}

All studies of $\mathrm{C}^{13}$ spectra of substituted alkanes have been confined to the first two or three members of each series $\left[{ }^{1,2}\right]$, mostly due to the low signal to noise ratio and difficulties with interpretation of the very complicated monoresonance spectra which consist of many overlapping multiplets, each due to an unequal methylene or methyl group. Total decoupling of all hydrogen nuclei simplifies these spectra and at the same time provides an up to more than sixfold enhancement of peak values $\left[{ }^{3}\right]$. In fact, $\mathrm{C}^{13}$ double resonance spectra provide the only practical means. for the study of carbon chemical shifts in complicated molecules with many unequal nuclei.

All $\mathrm{C}^{13}$ chemical shifts were measured at $15.1 \mathrm{MHz}$ from absorption spectra, using frequency sweep $(15 \mathrm{~Hz} / \mathrm{sec})$ and a very strong perturbing rf field with an amplitude $\gamma_{2}$ about $0.7 \mathrm{kHz}$. This technique provides high sensitivity, is no more difficult to apply than monoresonance and allows the use of a frequency counter for direct measurement of chemical shifts. The resonance condition for the irradiated protons is independent of the sweep and only 1 to 3 irequency settings are needed $\left[{ }^{3,5}\right]$. All shifts are averages from 6 measurements and referred to external carbon disulfide. Since fixed sample containers with $15 \mathrm{~mm}$ o.d. were used, resolution and accuracy were both about $0.4 \mathrm{ppm}$, but this proved to be sufficient for the present purposes, since very close-spaced lines $(\Delta \delta<1$ $\mathrm{ppm})$ are difficult to assign unequivocally. The results of chemical shift measurements are summarized in table 1 , together with some previous values reported by Grant and Paul $\left[{ }^{4}\right]$, Spiesecke and Schneider $\left[{ }^{1}\right]$, and others.

Selective saturation (mostly of the $\alpha$-carbon atoms), monoresonance spectra and regular systematic trends in homologous series were used for spectral assignment.

It has been shown in an earlier paper $\left[{ }^{17}\right]$ that the double bond in 1 -alkenes affects the chemical shifts of immediate neighbours only, leading to a paramagnetic shift of about $2 \mathrm{ppm}$. The relative shift of $\alpha$-methylene carbon atoms in all trans isomers is rather similar in magnitude, but in cis isomers the nonbonded 1,4-interaction interferes, leading to a small diamagnetic shift $\left[{ }^{7}\right]$. In 1-alkynes the magnetic anisotropy of the triple bond brings about a large diamagnetic shift (about $11 \mathrm{ppm}$ ) of the $\alpha$-carbon resonance, but the effect is again limited to this atom only. 


\section{$\mathrm{C}^{13}$ chemical shifts $\delta_{\mathrm{CS}_{2}}$ of substituted alkanes, in ppm from external carbon disulfide}

\begin{tabular}{c|c|c|c|c|c|c|c|c|c|c}
\hline \multirow{2}{*}{ No. Compound } & \multicolumn{10}{c}{ Carbon atom $^{1}$} \\
\cline { 2 - 7 } & $\mathrm{C}_{1}$ & $\mathrm{C}_{2}$ & $\mathrm{C}_{3}$ & $\mathrm{C}_{4}$ & $\mathrm{C}_{5}$ & $\mathrm{C}_{6}$ & $\mathrm{C}_{7}$ & $\mathrm{C}_{8}$ & $\mathrm{C}_{9}$ & $\begin{array}{c}\text { Re- } \\
\text { marks }\end{array}$ \\
\hline 1 & 2 & 3 & 4 & 5 & 6 & 7 & 8 & 9 & 10 & 11 \\
\hline
\end{tabular}

\section{n-Alkanes}

1. Methane

2. Ethane

3. Propane 2

4. n-Butane

5. n-Pentane

6. n-Hexane

7. n-Heptane

8. n-Octane

n-Alkynes

9. 1-Pentyne

10. 1-Hexyne

12. 1-Octyne

Alkylbenzenes ${ }^{3}$

13. Toluene

14. Ethylbenzene

15. n-Butylbenzene

16. $n$-Amylbenzene Alkylcyclo-

17. hexanes 4

17. Methylcyclohexane

18. Ethylcyciohexane
$n$-Butylcyclo-

19. n-Butylcyclo-

hexane
1-Alky!cyclo-
pentenes ${ }^{5}$

20. 1-Ethylcyclopentene
1-n-Propylcyclopentene

22. 1-n-Butylcyclopentene 1-Alkylcyclohexenes ${ }^{5}$

23. 1-Methylcyclohexene

24. 1-Ethylcyclohexene

25. 1-n-Propylcyclohexene

26. 1-n-Butylcyclohexene

3-Alkylcyclohexenes ${ }^{5}$

27. 3-Methylcyclohexene

28. 3-Ethylcyclohexene

29. 3-n-Butylcyclohexene 4-Alkylcyclohexenes 5

30. 4-Methylcyclohexene

31. 4-Ethylcyclohexene

32. 4-n-Propylcyclohexene

33. 4-n-Butylcyclohexene

Carboxylic acids

34. Formic acid

35. Acetic acid

36. Propionic acid

37. n-Butyric acid

38. n-Valeric acid

39. n-Caproic acid

40. n-Enanthic acid
195.8

178.1

$180.5 \quad 168.7$

$180.0 \quad 171$.

$179.8 \quad 170.8$

$\begin{array}{ll}179.8 & 170.7\end{array}$

$\begin{array}{ll}179.7 & 170.7\end{array}$

125.5

125.1

125.1

123.5

110.1

109.7
109.6

109.6

$108.5 \quad 174.1$

172.4

$\begin{array}{ll}164.3 & 177.9 \\ 157.4 & 159.4\end{array}$

$\begin{array}{ll}157.7 & 161.8\end{array}$

$\begin{array}{ll}170.5 & 179.3 \\ 161.8 & 170.5\end{array}$

180.5

158.

161.7

161.3

161.3

161.7

164.2

164.0

180.0

170.8

161.3

164.0

179.8

$170.7 \quad 179.8$

$\begin{array}{lll}161.3 & 170.7 & 179.7\end{array}$

$\begin{array}{ll}171.6 & 180.6\end{array}$

$162.6 \quad 171.3$

$164.4 \quad 161.8$

$163.3 \quad 163.3$

179.6

$170.1 \quad 178.5$

$\begin{array}{lll}160.5 & 169.1 & 1776\end{array}$
$[1]$
I1]
$[5]$
$[3]$
$[3]$
$[3]$
$[3]$
$[3]$

$[7,14,15]$

[9]
169.9

$162.7 \quad 181.6$

$155.7 \quad 163.8$

169.4

160.4

162.7

169.9

161.8

153.1

155.5

171.3

164.8

156.7

182.6

163.1

169.5

178.5

170.7

164.2

153.7

156.4

$172.8 \quad 178.8$

163.9

$169.9 \quad 179.0$

27.0

15.6

12.1

12.5

12.5
12.7

12.6
174.2

166.1

$157.1 \quad 174.6$

159.1

159.2

158.6
$165.8 \quad 170.2$

$168.5 \quad 161.1$

$167.7 \quad 163.2$
$174.6 \quad 179.1$
178.9

$169.5 \quad 178.3$ 


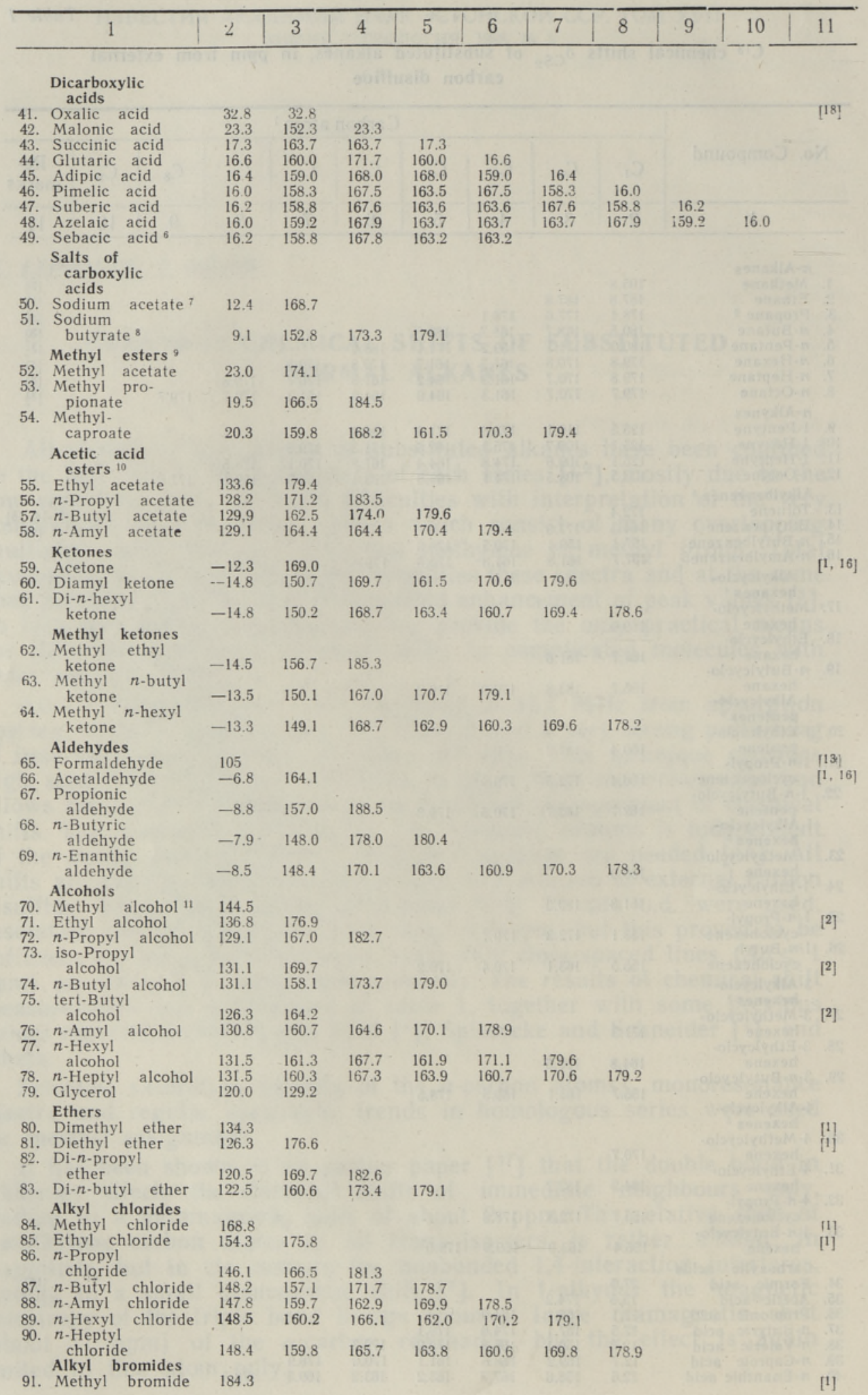




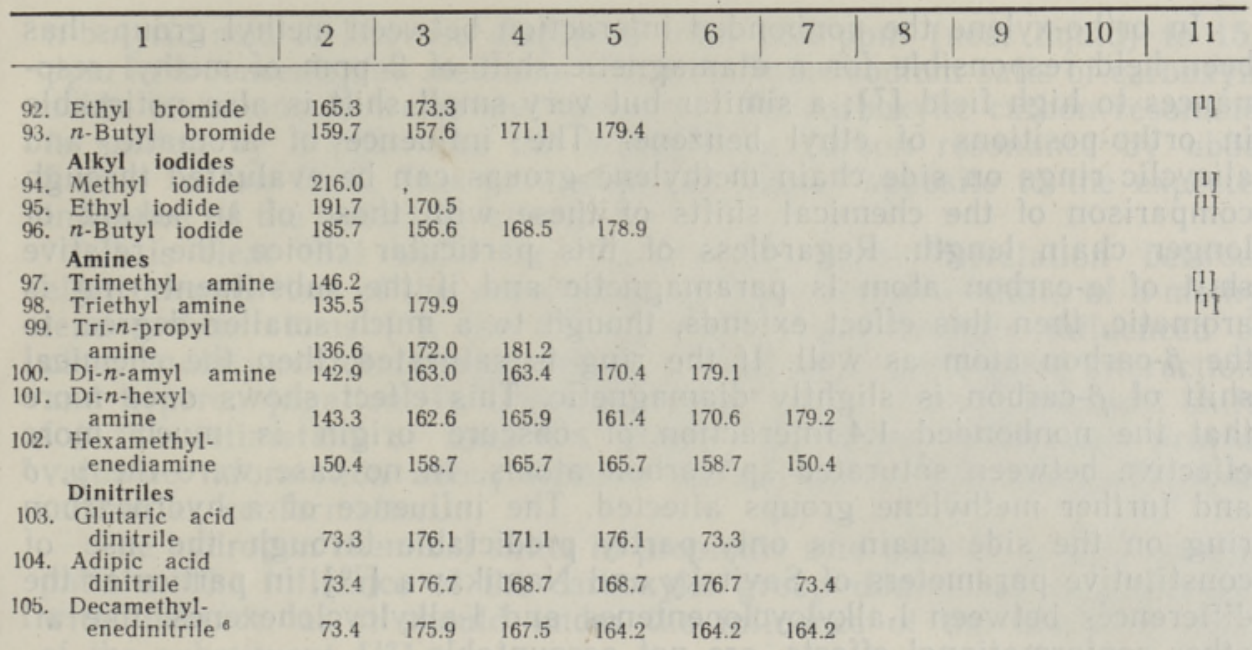

1) The numbering always begins with the first non-cyclic carbon atom that forms an integral part of the substituent group (as in acids) or is nearest to it (as in alcohols). If the polar substituent group is in the middle of the molecule, then the numbering begins there as well (ethers, ketones).

2) $\delta_{\mathrm{CS}_{2}}=\delta_{\mathrm{C}_{6} \mathrm{H}_{6}}+65.0$, for other alkynes see [ $\left.{ }^{5}\right]$.

3) $\mathrm{C}^{13}$ chemical shifts $\delta_{\mathrm{CS}_{2}}$ of the substituted aromatic ring

\begin{tabular}{l|c|c|c|c}
\hline Compound & $\mathrm{C}_{1}$ & $\mathrm{C}_{2,6}$ & $\mathrm{C}_{3,5}$ & $\mathrm{C}_{4}$ \\
\hline $\begin{array}{l}\text { Toluene } \\
\begin{array}{l}\text { Ethyl } \\
\text { benzene }\end{array}\end{array}$ & 55.9 & 64.4 & 65.2 & 68.1 \\
$\begin{array}{l}n \text {-Butyl } \\
\text { benzene }\end{array}$ & 50.5 & 65.3 & 64.9 & 68.1 \\
$\begin{array}{l}\text { n-Amyl } \\
\text { benzene }\end{array}$ & 51.1 & 65.2 & 65.2 & 67.9
\end{tabular}

4) For the $\mathrm{C}^{13}$ chemical shifts of the ring see $\left[{ }^{6}\right]$.

5) For the $C^{13}$ chemical shifts of the ring see $\left[{ }^{8}\right]$.

6) First half of the molecule.

7) Concentrated solutions in methanol.

8) Concentrated solution in water.

9) $\mathrm{C}^{13}$ chemical shifts of the methoxyl groups are $142.7 \mathrm{ppm}$ in methyl acetate, 142.9 $\mathrm{ppm}$ in methyl propionate and $142.6 \mathrm{ppm}$ in methyl caproate.

10) $\mathrm{C}^{13}$ chemical shifts $\delta_{\mathrm{CS}_{2}}$ of the acetyl groups

\begin{tabular}{|c|c|c|c|c|}
\hline & Ethyl & n-Propyl & n-Butyl & $n$-Amyl \\
\hline $\mathrm{CO}$ & 23. & 23.8 & 23.7 & 23.4 \\
\hline $\mathrm{CH}_{3}$ & 173.4 & 173.2 & 173.4 & 172.9 \\
\hline
\end{tabular}

11) $\mathrm{C}^{13}$ chemical shift of sodium methylate in methanol $144.1 \mathrm{ppm}$. 
In ortho-xylene the nonbonded interaction between methyl groups has been held responsible for a diamagnetic shift of $2 \mathrm{ppm}$ of methyl resonances to high field $\left[{ }^{7}\right]$; a similar but very small shift is also noticeable in ortho-positions of ethyl benzene. The influence of aromatic and alicyclic rings on side chain methylene groups can be evaluated through comparison of the chemical shifts of these with those of an alkane of longer chain length. Regardless of this particular choice, the relative shift of $\alpha$-carbon atom is paramagnetic and if the substituent ring is aromatic, then this effect extends, though to a much smaller degree, to the $\beta$-carbon atom as well. If the ring is saturated, then the chemical shift of $\beta$-carbon is slightly diamagnetic. This effect shows once more that the nonbonded 1,4-interaction of obscure origin is much more effective between saturated $\mathrm{sp}^{3}$-carbon atoms. In no case were the $\gamma, \delta$ and further methylene groups affected. The influence of a hydrocarbon ring on the side chain is only partly predictable through the use of constitutive parameters of Savitsky and Namikawa $\left[{ }^{10}\right]$, in particular the differences between 1-alkylcyclopentenes and 1-alkylcyclohexenes, like all other conformational effects, are not accountable.

The data for $\mathrm{C}^{13}$ chemical shifts of acids $\left[{ }^{18}\right]$, alcohols and other substituted alkanes show that in addition to the influence of the substituent group, the total chain length plays an important role. Internal consistency for the chemical shifts in all members of a homologous series is achieved if the measured shifts are compared with the corresponding chemical shifts of a hydrocarbon of equal chain length, including the heteroatoms of the substituent group. Formic acid is thus compared with ethane, not methane. In carboxylic acids the carboxyl resonance is shifted by about $159 \mathrm{ppm}$ and $\alpha$-methylene carbon resonance by $2.7 \mathrm{ppm}$ to lower field and $\beta$-methylene resonance by $3.7 \mathrm{ppm}$ to higher field. The $3.7 \mathrm{ppm}$ diamagnetic shift is rather peculiar, but a recent investigation of carboxylic acids by the X-ray diffraction method $\left[{ }^{11}\right]$ provides some insight into it. X-ray diffraction study of numerous carboxylic acids led the authors to the conclusion that "the conformation of carboxylic acids and their derivaties is independent of the space group to which the crystal belongs and of the ionic or molecular character or of the hydrogen bond scheme of the structure". They also found that the conformation of molecules of carboxylic acids in crystalline state is inherent to free molecules. It was determined that in the crystalline state the $\beta$-carbon atom is always very close to the carboxyl group, the mean distance between the carbon and oxygen atoms being only $2.85 \AA$. This distance is by about $0.4 \AA$ shorter than the normal Van-der-Waals contact distance after Pauling $\left[{ }^{11}\right]$.

The chemical shifts in dicarboxylic acids provide a further illustration for the constancy of the influence of a polar group. If one uses the chemical shifts of a normal alkane with $n+2$ carbon atoms and the relative chemical shifts for $\alpha-, \beta$, and carboxyl carbon atoms, then the chemical shifts of all methylene carbon atoms in dicarboxylic acids can be calculated with high accuracy. Deviations from experimental values do not exceed $0.5 \mathrm{ppm}$ in 80 per cent of the cases with $1.5 \mathrm{ppm}$ as the largest value (in malonic acid). The error for carboxylic carbon atoms is larger, but does not exceed $3 \mathrm{ppm}$. The conjugated carboxyl groups of oxalic acid show an abnormally large diamagnetic shift. The larger diamagnetic chemical shifts of carboxylic carbon atoms in dicarboxylic acids as compared with monocarboxylic acids are caused by a solvent effect since the former were studied in methanol solution while the latter were used as neat liquids. The $\mathrm{C}^{13}$ resonance of the carboxyl group in 
n-butyric acid is likewise displaced from $12.5 \mathrm{ppm}$ (neat liquid) to 15.9 ppm in a concentrated methanol solution. In the sodium salts of carboxylic acids (solutions in water and methanol) the carboxylic carbon resonance is shifted by $3 \mathrm{ppm}$ and the $\alpha$-methylene carbon resonance by about $5 \mathrm{ppm}$ to low field. This paramagnetic shift is opposite to the expected influence of the inductive effect.

It is clear that while there is a very crude correlation between electronegativities of the substituents and the chemical shifts of $\alpha$-methylene carbon atoms $\left[{ }^{1}\right]$, the $C^{13}$ resonances are strongly influenced by other, mainly conformational, effects as well as by nonbonded interactions and hyperconjugation. It is not advisable to use the $\mathrm{C}^{13}$ chemical shifts for the estimation of inductive effects, but these shifts can provide valuable information about electron delocalization and especially about molecular conformation.

The hydrogen chemical shifts in propionic acid provide a much simpler pattern. The influence of the carboxylic group diminishes monotonously with distance, as it should under the influence of the inductive effect of the substituent $\left[{ }^{12}\right]$.

The chemical shifts in esters are rather similar to those in acids. The methoxyl carbon shift is consistently lower by $2 \mathrm{ppm}$ from the shift in methanol. The specific diamagnetic shift of $\beta$-methylene carbon resonances is present in all esters, ketones and aldehydes and even somewhat larger than in acids. It is very probable that the preferred conformation of these molecules is similar to that of acids.

The same nonbonded 1,4-interaction or some similar mechanism appears to be active in alcohols and amines, where there is a specific diamagnetic shift about $3 \mathrm{ppm}$ of the $\gamma$-methylene carbon resonances. The mean value for the paramagnetic shift of $\alpha$-methylene carbon resonances is $40 \mathrm{ppm}$ in alcohols and only about $1 \mathrm{ppm}$ for the $\beta$-carbon atoms. The reference compound in this case is a normal alkane with $n+1$ carbon atoms. In the case of secondary alcohols and glycerol a better fit is achieved by the use of branched hydrocarbons as references (3-methyl pentane for glycerol). The chemical shifts of ethers are very similar to those of alcohols. Apart from theoretical interest, these selective shifts may be useful for chemical analysis. Experimental and calculated chemical shifts for 4-octanol are given in Table 2. Chemical shifts of the reference compound, 4-methyloctane, were calculated, using the data for n-octane and constitutive parameters of Savitsky and Namikawa $\left[{ }^{10}\right]$.

Table 2

$\mathrm{C}^{13}$ chemical shifts $\delta_{\mathrm{CS}_{2}}$ of 4-octanol

\begin{tabular}{l|c|c|c|c|c|c|c|c}
\hline & $\mathrm{C}_{1}$ & $\mathrm{C}_{2}$ & $\mathrm{C}_{3}$ & $\mathrm{C}_{4}$ & $\mathrm{C}_{5}$ & $\mathrm{C}_{6}$ & $\mathrm{C}_{7}$ & $\mathrm{C}_{8}$ \\
\hline Calcd. & 179.7 & 173.7 & 153.4 & 116.9 & 156.1 & 164.3 & 170.7 & 179.7 \\
Exptl. & 179.1 & 174.2 & 153.1 & 122.3 & 155.5 & 165.0 & 170.2 & 179.1 \\
$\Delta$ & -0.6 & +0.5 & -0.3 & +5.4 & -0.6 & +0.7 & -0.5 & -0.6
\end{tabular}

The deviations for methylene and methyl groups are only slightly larger than experimental error. It is possible that a different increment should be used to describe the influence of hydroxyl group on the chemical shift of an $\alpha$-methine group. It is immediately clear that the chemical shifts of other isomeric octyl alcohols would be very different. The easy predictability of $\mathrm{C}^{13}$ chemical shifts in substituted normal alkanes makes these spectra useful for identification purposes. 
Among the alkyl halides the chlorides behave quite similarly to alcohols; there are relative paramagnetic shifts about $23 \mathrm{ppm}$ in $\alpha$ position and $2 \mathrm{ppm}$ in $\beta$-position. The diamagnetic shift of $\gamma$-methylene carbon resonance is $1.4 \mathrm{ppm}$ in chlorides and $8.3 \mathrm{ppm}$ in bromides, but surprisingly in iodides there is a paramagnetic shift of $2.6 \mathrm{ppm}$. The large diamagnetic shifts of $a$-carbon atoms in iodides are only partly understood $\left[{ }^{19}\right]$, but provide another example of the secondary role of the inductive effect in carbon spectra.

The nitrile group is rather similar to carbon-carbon triple bond $\left[{ }^{18}\right]$ and causes a diamagnetic shift about $15 \mathrm{ppm}$ of $\alpha$-methylene carbon resonances, but in addition to this a $5 \mathrm{ppm}$ shift of $\beta$-carbon resonances as well. The magnetic anisotropy of this group is apparently larger than the anisotropy of triple bond, but an exact evaluation is difficult since other effects interfere.

In summary, the results on substituted alkanes reveal a strong dependence of $\mathrm{C}^{13}$ chemical shifts on conformational factors in addition to the inductive effect. Magnetic anisotropy has a significant influence only in the case of triple bonds.

\section{REFERENCES}

1. Spiesecke H., Schneider W. G., J. Chem. Phys., 35, 722 (1961).

2. S a vitsky G. B., N a m ik a w a K., J. Phys. Chem., 67, 2430 (1963).

3. Lippma E., Pehk T., P ast J., Изв. АН ЭСС̈Р, Физ. Матем., 16, № 3 , 345(1967).

4. Gra nt D. M., P a u 1 E. G., J. Am. Chem. Soc., 86, 2984 (1964).

5. R ang S., P ehk T., Li p pma a E., E is en O., Изв. АН ЭССР, Хим. Геол., 16. № 4, 346 (1967).

6. Пехк Т., Ли и п м а Э., Изв. АН ЭССР, Хим. Геол., 17, № 3 (1968).

7. Woolfenden W. R., Grant D. M., J. Am. Chem. Soc., 88, 1496 (1966).

8. Пехк Т., Р анг С., Эйзен О., Ли п п а а Э., Изв. АН ЭССР, Хим. Геол., 17, № 3 (1968).

9. Dha m i K. S., S t o thers J. B., Can. J. Chem., 43, 479 (1965).

10. S a vitsk y G. B., N a m i k a w a K., J. Phys. Chem., 68, 1956 (1964).

11. Kanters J. A., Kroon J., Peerdeman A. F., Schoone J. C., Tetrahedron, 23, 4027 (1967).

12. C a v a n a ugh J. R., D a il e y B. P., J. Chem. Phys., 34, 1099 (1961).

13. L a uterbur P. C., J. Chem. Phys., 26, 217 (1957).

14. Frei K., Bernistei n H. J., J. Chem. Phys., 38, 1216 (1963).

15. A 1 g e r T. D., G r a nt D. M., P a ul E. G., J. Am. Chem. Soc., 88, 5397 (1966).

16. St others J. B., La uterbur P. C., Can. J. Chem., 42, 1563 (1964).

17. Р анг С., Липпм а Э Э., Пехк Т., Эйзен О., Изв. АН ЭССР, Хим. Геол., 17, № 3 (1968).

18. L i p p m a a E., P e h k T., Kemian Teollisuus, 24, 1001 (1967).

19. S chaefer T., Reynolds W. F., Yonemoto T., Can. J. Chem., 41, 2969 (1963).

Academy of Sciences of the Estonian SSR, Received April 9, 1968 Institute of Cybernetics

\section{E. LIPPMAA, T. PEHK}

\section{SUSINIK-13 KEEMILISED NIHKED ASENDATUD NORMAALSETES ALKAANIDES}

Uuriti asendava rühma toimet küllastatud süsivesinikahela $\mathrm{C}^{13}$ keemilistele nihetele. Selgub, et peale induktiivse efekti sōltuvad need ahela konformatsioonist. Nihked on vastavate inkrementide abil arvutatavad ja $\mathrm{C}^{13}$ spektrid on kasutatavad orgaaniliste ühendite identifitseerimisel.

\section{Э. ЛИППМАА, Т. ПЕХК}

\section{ХИМИЧЕСКИЕ СДВИГИ УГЛЕРОДА-13 В ЗАМЕЩЕННЫХ НОРМАЛЬНЫХ АЛКАНАХ}

Исследовалось влияние заместителя на химические сдвиги $\mathrm{C}^{13}$ в насыщенной цепи. Оказалось, что эти сдвиги, кроме индуктивного эффекта, весьма чувствительны и к конформационным факторам. Химические сдвиги $\mathrm{C}^{18}$ могут быть вычислены с помощью соответствующих инкрементов и использованы для идентификации органических соединений. 